\title{
An Analysis of Gender Representations in an English Language Textbook
}

\section{India Roberts}

University of Birmingham

\section{Reference Data}

Roberts, I. (2021). An analysis of gender representations in an English language textbook. In P. Clements, R. Derrah, \& P. Ferguson (Eds.), Communities of teachers \& learners. JALT. https://doi. org/10.37546/JALTPCP2020-38

This study is an initial investigation of how gender is represented in English language textbooks adapted for schools in the Middle East. A content analysis was carried out to investigate the adapted for schools in the Middle East. A content analysis was carried out to investigate the
following areas: visibility in written texts and images; masculine generic constructions; order of mention; and character roles, occupations, actions, and interactions. The findings indicate that both genders have been portrayed equally in written texts in all areas other than masculine generic constructions. However, visibility in images is biased towards males, indicating a need for review. The findings have implications for materials developers, teachers, and trainers, and suggestions are provided for future research.

本稿は、中東の公立学校向けに作成された教科書でジェンダーが゙゙のように表現されているかについて検証したす。内容 分析では以下の領域に関して調查した。すなわち、文章と画像における可視性、男性的な一般的構造、言及の順序、キャラクタ 一の役敖、行動、職業、および相互作用である。調查結果によると、文章においては、男性的な一般的構造以外のすべての分野 で男女が同等に描かれていることがかかった。しかい、、画像での可視性は男性に偏っており、見直しの必要性が認められた。本 稿の結果は、教材開発者、教師、およびトレーナーにとつて有用であり、今後の研究のための提案を含むものである。

C chools are seen as an important agent of socialisation. In particular, textbooks play $\checkmark$ an important role in influencing students' views of gender roles in society (Setyono, 2018). The presentation of gender in textbooks is an area of concern globally, as previous studies indicate that men and women are not always represented equally. Through an initial investigation, this paper addresses the way in which both genders are represented in an English language textbook used in the Middle East.
The textbook analysed was developed for the Middle East, specifically for the United Arab Emirates (UAE). Gender biases are still present in many societies, including the Middle East (Al-Qatawneh \& Al Rawashdeh, 2019). However, the UAE government has undertaken various initiatives based on principles of gender equality (Organisation for Economic Cooperation and Development, 2017), with measures taken to empower all members of society and to ensure that institutions achieve gender balance goals (AlQatawneh \& Al Rawashdeh, 2019). At the time of writing, the UAE is also in the process of educational reform. Curriculum and educational policy are now standardised across all public schools (Gobert, 2019). This movement to standardisation highlights the importance of evaluating the materials provided to schools nationwide. The present study focused on a textbook used for the subject of English language, and a content analysis was carried out to investigate the gender representations portrayed in the textbook. The results have implications for materials developers, teachers, and other stakeholders by raising awareness of the gender biases that may be present in textbooks in both texts and images and how they can be identified. I begin with a discussion of the literature relevant to gender biases in textbooks worldwide, before reporting on the analysis of gender representations found in the textbook. An overview of the results is followed by a discussion of their implications as well as recommendations and avenues for future research.

\section{Background}

Decades of research concerning the gender representations found in English language textbooks indicate that men and women have not always been represented equally (Blumberg, 2008). Before exploring the research further, it is necessary to explain what is meant by a representation. From a sociological perspective, a representation can be seen as a view of the world which can act as a guide for communication and the formation of reality (Brugeilles \& Cromer, 2009). The linguistic and visual representations portrayed in learning materials can transmit social and cultural biases as well as information 
about gender roles, as textbooks are perceived as authoritative and trustworthy sources of information (Lee \& Collins, 2008). It is important to investigate the representations found in textbooks to avoid isolating either gender from learning experiences. For example, in language, the use of the generic man and he to include women can cause female readers to feel distanced (Silveira, 1980).

One of the earliest studies investigating gender representations in textbooks was carried out by Hartman and Judd (1978). They found that women were less visible than men, were represented stereotypically, and were also ridiculed in jokes. Porreca (1984) carried out a systematic analysis of 15 commonly used EFL textbooks in the United States and investigated the following areas: omission (measuring the ratio of women to men in the text), firstness (the number of times men or women are mentioned first), occupational roles of both genders, nouns indicating men or women, masculine generic constructions, and the adjectives used to describe both genders. All but two textbooks were found to favour men in terms of linguistic representations, placing women in second place or in stereotyped roles. These studies have laid the foundation for a body of comparative studies that have found varying degrees of gender biases in textbooks worldwide (Brugeilles \& Cromer, 2009).

Blumberg (2008) has drawn attention to the similarities found throughout the body of research since these early studies: the underrepresentation of women in terms of visibility, titles, and names as well as stereotyped roles in occupations, actions, and attitudes portrayed. Jassey (1998, as cited in Blumberg, 2008) pointed out that "virtually all of the studies concluded that textbooks have not adequately reflected the range of women's roles and occupations in the real world" (p. 5).

Blumberg's (2008) observations have also been supported by similar studies focussing on textbooks in the Middle East (Al-Qatawneh \& Al Rawashdeh, 2019; Al Rabaa, 1985; Sulaimani, 2017; Tahan, 2015). In the UAE, Tahan (2015) found male biases through investigation of the EFL textbooks previously used in schools. Gender biases were found in favour of males through visibility in images and texts and in the occupations, roles, traits, and activities of each character. Al-Qatawneh and Al Rawashdeh (2019) found similar biases in an investigation of an Arabic language textbook used in UAE public schools and recommended that authors receive training on such issues.

\section{Response}

In response to calls for removal of the gender-based stereotypes found in educational materials, governments and organisations around the world, such as the United
Nations Educational, Scientific and Cultural Organization (UNESCO), have formulated guidelines for publishers and ministries. Research indicates that the representation of women in textbooks has generally improved, although inequalities remain (Blumberg, 2015). For example, Lee (2014) investigated whether the Japanese government's aim to promote gender equality through education was reflected in learning materials. Progress was observed in gender-neutral vocabulary and titles of address; however, bias was found through male firstness in texts, female omission, and stereotypical images. Blumberg (2015) found that in certain countries, attempts have been made to improve gender equality in textbooks as a result of policy reform, although they have not always been successful. Such outcomes raise the question of why biases remain.

Studies that look beyond the textbook may provide answers. Ullah and Ali (2012) investigated why efforts to reduce gender bias in textbooks in Pakistan were unsuccessful. Interviews with publishers, ministry officials, and other key stakeholders revealed a lack of awareness in the groups in charge of textbook production. Gouvias and Alexopoulos (2018) focused on teachers following a content analysis of Greek language textbooks. Following interviews, they concluded that teachers had a minimal awareness of the stereotypes present in textbooks or how to find them, indicating the need for training in gender issues (for a detailed discussion on specific countries and contexts, see Blumberg, 2015). These examples are not intended to generalise across cultures, but to show that stakeholders may not always be aware of the issues.

\section{Research Questions}

The present study adds to the research concerning textbooks used in the Middle East through an initial investigation of the gender representations in an English language textbook used by Grade 9 students in the UAE.

The following research questions were investigated:

RQ1. What are the patterns of gender representations in these textbooks?

RQ2. To what extent are any gender representations promoting stereotypes?

The Textbook

\section{Methodology}

The textbook analysed was a first edition of Volume 1 of the Bridge to Success Book 9 English language textbook (Bridge to Success, 2018). The Bridge to Success series was adapted from the Global English series from Cambridge University Press in collaboration 
with a team of specialists from the UAE. No further details are provided on the authors (Cambridge University Press, 2019). Bridge to Success is a course for Grades 1 to 12, and textbooks follow a skills-based syllabus. Each grade comprises 12 thematic units divided into three volumes. Volume 1 of Book 9 contains five units with the following unit titles: Household Routines, Habitat Interactions, Buildings and Structures, Design and Shape, and Personality Types. Units progress in skills and language, but they are not connected. The characters that appear in each unit do not recur throughout the textbook. Additionally, the textbook is accompanied by audio tracks for listening activities. Bridge to Success Book 9 targets Grade 9 students who study English at the Common European Framework of Reference for Languages (CEFR) level B1.

\section{Content Analysis Framework}

Content analysis was used as a systematic method of investigating the contents of the textbook. Porreca's (1984) categories and an adaptation of Brugeilles and Cromer's (2009) framework were used for the content analysis. Brugeilles and Cromer's framework is based on the ideas that gender representations are expressed through textbook characters and that the features of characters lead the reader to form a representation of what it means to be male or female (Brugeilles \& Cromer, 2009). Based on this notion, the framework was used to collect gender information about every character in the textbook. Men and women can be represented in both texts and images; therefore, the images and illustrations were also analysed.

\section{Procedure}

Information was collected manually from the images and the written contents from the first page of Unit 1 to the last page of Unit 5 using a hard copy of the textbook. Audio tracks were not included in the analysis. A data collection table adapted from Brugeilles and Cromer (2009) was used to collect information about each textbook character. Characters were numbered in order of appearance. The following details were collected about each character: age group, how they are identified, their role (e.g., main character), whether they are interacting with someone or alone, and if interacting with another character, which character they are interacting with and the nature of their relationship. Character actions were also recorded using categories suggested by Brugeilles and Cromer (2009). In addition to the number of male and female characters in the textbook, the following categories were adopted from Porreca (1984) and recorded in separate tables: all occupations mentioned in the textbook, all nouns referring to people, masculine generic constructions, and order of mention for any instance when two characters were mentioned together in a sentence. Images of both genders were also counted manually, and any characters that appeared in images were counted as a separate category. The author's results were compared with those of a rater with experience working in the UAE education context, familiarity with the textbook series, and an understanding of the issues relevant to the study. The rater wished to remain anonymous and as such asked that any potentially identifying details not be published. Any discrepancies were discussed and checked again in the textbook to ensure that the information collected was accurate or categorised appropriately. For example, discrepancies occurred in categorising character actions, where categories such as school and success overlapped. It was decided that both categories should be included in such instances.

\section{Results}

\section{Porreca's Categories}

As can be seen in Table 1 below, the number of male and female characters were wellbalanced in the text. The total number of characters in the text included those whose gender was not indicated, such as scientist. Specifically, there were 14 instances where a character's gender was not specified. In contrast, women were less visible in images, appearing in $20 \%$ of the total number of images of people, whereas males appeared in $80 \%$. Of the total number of images of people, $45 \%$ were images of named characters while the rest were unidentified.

Table 1

Number of Males and Females in Texts and Images

\begin{tabular}{lccc}
\hline & Characters in text & Images of people & Characters in images \\
\hline Female & $19(38 \%)$ & $4(20 \%)$ & $3(33.3 \%)$ \\
Male & $17(34 \%)$ & $16(80 \%)$ & $6(66.6 \%)$ \\
Total & 50 & 20 & 9 \\
\hline
\end{tabular}

Table 2 lists the nouns that referred to people in the textbook and how many times they occurred. Out of a total of 159 nouns, 12 nouns referred to females and 11 to males (the terms male and female are used to include individuals of all age groups), while the 
majority (136) did not refer to either gender. For example, in Unit 2 a sentence writing activity mentioned hunters and poachers with no indication of gender. Regarding occupations, as can be seen in Table 2, the majority (25 out of 29) were not associated with either gender. One female character was an artist, one was a painter, and there was one male engineer and one male farmer.

Table 2

Nouns in the Textbook That Refer to People

\begin{tabular}{llc}
\hline Gender & \multicolumn{1}{c}{ Nouns } & Total \\
\hline Female & $\begin{array}{l}\text { Artist (1), Aunt (2), Child (1), Mother (5), Mum (1), Painter (1), } \\
\text { Sister (1) }\end{array}$ & 12
\end{tabular}

Male $\quad$ Boys (1), Brother (5), Dad (1), Engineer (1), Farmer (1), Father (1), President (1)

Unspecified Author (4), Child/Children (4), Classmate (3), Contestant (1), Director (1), Doctor (2), Driver (2), Engineer (2), Family (6),

Farmer (1), Friend (7), Grandparent (2), Human (3), Hunter

(1), Interviewer (2), Judge (1), Man (human) (6), Parents (6),

Passenger (2), People (55), Player (1), Poacher (1), Researcher

(1), Scientist (2), Student (11), Teacher (5), Winner (2),

Worker (1), Writer (1)

Note. Noun frequencies are in brackets, and occupations are in bold.

Instances of masculine generic nouns were found in Unit 2 under the topic of habitats. In this instance, man, referring to human beings, appeared six times and was represented by the pronoun he on one occasion. Excluding this, the textbook authors have used neutral nouns to represent men and women in the majority of cases, as can be seen in Table 2.

Order of mention was investigated by identifying instances where male and female characters appeared together and noting which gender was mentioned first. A total of five pairs of characters were mentioned together in sentences. There were two situations where male characters were mentioned before female characters, and there was one situation where a female character was mentioned before a male character. In Unit 4, characters were identified as "Waleed and his mother." In Unit 5 there was a brother and sister pair introduced as "Dalal and her brother Ibrahim" who were later referenced on two occasions with "Ibrahim and Dalal's story."

\section{Characters' Roles, Actions, and Interactions}

This section reports information collected from Brugeilles and Cromer's (2009) framework. Regarding roles in the textbook, 37 characters were counted in the position of actor, indicating they were the main character in a text. Of these characters, $18(48 \%)$ were female, 14 (38\%) were male, and the remainder were non-gendered. There were three male and two female characters acting as extras, indicating that they were included in a text but not in a main character role. The remaining characters were neither actors nor extras.

Regarding the actions assigned to characters, male and female characters were found to be involved in actions under the categories listed in Table 3. For example, domestic actions involved cooking and doing chores, recreational actions included sports and hobbies, and the negative action involved a character missing a bus and forgetting something.

Table 3

Number of Actions Associated with Male and Female Characters

\begin{tabular}{lcc}
\hline Action category & Female characters & Male characters \\
\hline caring & 1 & 0 \\
domestic & 7 & 7 \\
recreational & 5 & 0 \\
negative & 1 & 0 \\
occupational & 1 & 2 \\
routine & 6 & 5 \\
school & 2 & 2 \\
success & 4 & 3 \\
social & 2 & 2 \\
\hline
\end{tabular}

For the category of interactions, 26 characters appear by themselves, and 24 interact. Interestingly, looking at the interactions in closer detail reveals that mixed-gender interactions always occur with family, while in formal contexts one gender is unspecified (for example, as interviewer and interviewee or teacher and student). 


\section{Discussion}

In this study, the author investigated the patterns of gender representations in the textbook analysed and the extent to which any gender representations were promoting stereotypes. It was found that the textbook presented gender in a balanced way in the majority of areas investigated. However, visibility in images was biased towards males, and masculine generic constructions were observed.

In terms of visibility, the textbook presented a balanced distribution of male and female characters in the text, the majority of which were children, which is appropriate as they are the intended audience. Visual representations are also an important consideration (Porreca, 1984), and in this category, females were underrepresented as they only appeared in four images. To explore why, authors who had contributed to this textbook series were consulted through informal discussion (the authors wished to remain anonymous). One author explained that authors have to follow cultural appropriacy guidelines when creating learning materials. For example, in pictures, women should be dressed in modest clothing, and Emirati women should be shown with their hair covered. As such, culturally appropriate images of females can be difficult to locate from image resource banks. The authors further explained that they work to tight deadlines and do not always have time to search for suitable images (personal communication, February 2019). Such conditions might contribute to the unequal distribution of visual representations observed in the textbook. Nevertheless, due to the importance of equal representations, efforts should be made to ensure women are not underrepresented, and a review of images is recommended.

As mentioned, excluding masculine generics, the authors used neutral words to represent men and women in the majority of categories. While the inclusion of two male characters with the occupations of engineer and farmer could be seen as stereotypical, conclusions cannot be drawn from two examples. Regarding order of mention, there were no patterns of bias as there were only two male and female pairs mentioned together, so it is also difficult to draw conclusions for this category. Considerations of cultural context may have contributed to the low number of such instances. It is important to consider that within the Middle East some societies are religiously conservative, and gender mixing is not customary outside of family or formal contexts (Al-Jenaibi, 2015). The fact that characters were identified as his mother or her brother may serve the purpose of emphasising that two interacting characters of different genders are related for cultural appropriacy for the context.
In the context of male and female representations, overall, the current textbook is an improvement on previous English textbooks used in the UAE. Tahan (2015) found male biases in most areas, except for masculine nouns. Women appeared in $40 \%$ of illustrations in stereotyped roles, while in the present study, women appeared in $20 \%$ of images of people and did not appear to be depicted in stereotyped roles. Due to the small sample size, images were evaluated for stereotypes based on the judgement of the author. The imbalance in images, on the other hand, may send the message that women are not important enough to be included, and the use of man to refer to human beings could distance female students (Porreca, 1984). However, teachers could be given awareness training as part of their professional development to identify and overcome any gender biases, which would help to remove any potential biases found in learning materials The textbook could be supplemented with extra visuals in bespoke worksheets created by teachers to bring balance to representations in images. Teachers could also address this issue in the classroom by making students aware of bias and allowing them to make informed choices in how they speak (Mustapha \& Mills, 2015). For example, when man is used to refer to human beings, students could be asked what comes to mind when they read or hear this word in order to initiate a class discussion. Teachers could use question prompts to help students explore why the use of man could be problematic, and suitable synonyms could be explored. Students also need to be able to understand terms that they may encounter in English and their implications, even if they choose not to include them in their personal language use. Despite an increased global awareness of the gender biases that can be found in educational materials (Blumberg, 2015), non-neutral terms may still be in use or may be found in publications encountered by students.

As mentioned previously, textbooks present representations which can act as a guide for reality. Brugeilles and Cromer (2009) recommend either relating textbook representations to the reality of the country where they are used or representing situations in other countries in order to show both genders in a variety of roles. An exception to this would be when situations might be viewed as too far from the norm for a specific population. In the case of the textbook analysed, the majority of representations were balanced, in line with societal developments and UAE gender equality goals (Al-Qatawneh \& Al Rawashdeh, 2019). Closer analysis revealed that characters interacted with family members or characters whose gender was not specified. This could be seen as a representation that reflects what is culturally acceptable for the context. Findings like this may not be apparent at the surface level, which emphasises the value of Brugeilles and Cromer's framework in bringing the details of interactions to 
attention. While useful, analysis of Porecca's (1984) categories alone would not provide the same insight. This highlights the importance of careful consideration of the methods employed when investigating gender representations, as a closer analysis may reveal sociocultural details applicable to the specific contexts for which materials are intended.

\section{Conclusion}

This research has addressed gender representations in a textbook used in the UAE and is a starting point for future research. Although the results are encouraging in most areas investigated, there are some limitations. Firstly, only one textbook from the series was analysed. Future research comparing textbooks at the primary, middle, and high school level would provide a clearer picture of the balance of representations in the Bridge to Success series and whether representations differ at these stages. Additionally, formal interviews with authors and other stakeholders would provide further insight into the findings discussed. There is still a need for investigation of gender representations in school textbooks worldwide, and it is vital to investigate the effect that biases may have on readers' perceptions of themselves and others. Teachers should additionally receive training in gender representations and their potential manifestations so that when biases do occur, they can work with students to create awareness and overcome them. Furthermore, materials developers and publishers should establish guidelines so that everyone involved is aware of the potential biases that can occur and how they can be overcome.

\section{Bio Data}

India Roberts is an education professional with over 10 years of experience in English language education and curriculum development. Her research interests include materials development, language, cognitive linguistics, and mental health.

\section{References}

Al-Jenaibi, B. (2015). The needs and priorities of women in the UAE: Identifying struggles and enhancing satisfaction of employment, education, health care, and rights. Contemporary Review of the Middle East, 2(3), 238-268. https://doi.org/10.1177\%2F2347798915601590

Al-Qatawneh, S., \& Al Rawashdeh, A. (2019). Gender representation in the Arabic language textbook for the ninth grade approved by the Ministry of Education for use in schools in the United Arab Emirates (UAE). Studies in Educational Evaluation, 60, 90-98. https://doi. org/10.1016/j.stueduc.2018.12.001
Al Rabaa, S. (1985). Sex division of labour in Syrian school textbooks. International Review of Education, 31(1), 335-348. https://doi.org/10.1007/bf02262586

Blumberg, R. L. (2008). The invisible obstacle to educational equality: Gender bias in textbooks. Prospects, 38(3), 345-361. https://doi.org/10.1007/s11125-009-9086-1

Blumberg, R. L. (2015). Eliminating gender bias in textbooks: Pushing for policy reforms that promote gender equity in education. Paper commissioned for the EFA Global Monitoring Report 2015 Education for All 2000-2015: Achievements and Challenges. UNESCO.

Bridge to success book 9 (Vol. 1). (2018). Cambridge University Press and the United Arab Emirates Ministry of Education, 2018.

Brugeilles, C., \& Cromer, S. (2009). Promoting gender equality through textbooks: A methodological guide. UNESCO.

Cambridge University Press (2019). United Arab Emirates: Capacity development: Bridge to success. https://www.cambridge.org/us/educationreform/case-studies/bridge-success/

Gobert, M. T. (2019). Transformation in English language education in the UAE. In K. Gallagher (Ed.), Education in the United Arab Emirates (pp. 113-126). Springer. https://doi.org/10.1007/978981-13-7736-5_7

Gouvias, D., \& Alexopoulos, C. (2018). Sexist stereotypes in the language textbooks of the Greek primary school: A multidimensional approach. Gender and Education, 30(5), 642-662. https://doi. org/10.1080/09540253.2016.1237620

Hartman, P. L., \& Judd, E. L. (1978). Sexism and TESOL materials. TESOL Quarterly, 12(4), 383-393. https://doi.org/10.2307/3586137

Lee, J. (2014). A hidden curriculum in Japanese EFL textbooks. Linguistics and Education, 27(1), 3953. https://doi.org/10.1016/j.linged.2014.07.002

Lee, J., \& Collins, P. (2008). Gender voices in Hong Kong English textbooks-some past and current practices. Sex Roles, 59(1), 127-137. https://doi.org/10.1007/s11199-008-9414-6

Mustapha, A. S., \& Mills, S. (2015). Gender representation in learning materials. Taylor and Francis.

The Organisation for Economic Co-operation and Development (2017). Gender balance guide: Actions for UAE Organisations. UAE Gender Balance Council. https://www.oecd.org/gov/genderbalance-guide-uae-2017.pdf

Porreca, K. L. (1984). Sexism in current ESL textbooks. TESOL Quarterly, 18(4), 705-724. https:// doi.org/10.2307/3586584

Setyono, B. (2018). The portrayal of women in nationally-endorsed English as a foreign language (EFL) textbooks for senior high school students in Indonesia. Sexuality \& Culture, 22, 1077-1093. https://doi.org/10.1007/s12119-018-9526-2

Silveira, J. (1980). Generic masculine words and thinking. Women's Studies International Quarterly, 3 , 165-178. https://doi.org/10.1016/s0148-0685(80)92113-2 


\section{JALT2020}

COMMUNITIES OF

Roberts: An Analysis of Gender Representations in an English Language Textbook

Sulaimani, A. (2017). Gender representation in EFL textbooks in Saudi Arabia: A fair deal? English Language Teaching, 10(6), 44. https://doi.org/10.5539/elt.v10n6p44

Tahan, A. A. (2015). An investigation of gender representation in EFL textbooks used at public schools in the UAE. The British University in Dubai (BUiD).

Ullah, H., \& Ali, J. (2012). Male hegemony through education: Construction of gendered identities. Multidisciplinary Journal of Gender Studies, 1(3), 215-242. https://doi.org/10.4471/ generos.2012.11 